\title{
REVOLUTION RECONSIDERED: INSTITUTION-BUILDING IN A MORAL VOID
}

\author{
RUDOLF L. TŐKÉS \\ University of Connecticut, CT, \\ USA
}

The series of events that began in early 1989 and culminated in the free elections in March 1990 have been characterized as "revolution" of one of four kinds.

According to the British journalist T. G. Ash, it was a "refolution" suggesting that what happened in Hungary was more than reform but less than a revolution. ${ }^{1}$ Though intended as a clever oxymoron, the term is grossly misleading as it obscures and trivializes the qualitative difference between the point of departure and the point of arrival, that is, the difference between dictatorship and democracy

Acccording to the former democratic oppositionist ideologue János Kis and several others who chose this formulation, the Hungarian events amounted to a "lawful revolution." "The term stresses the notion of legal continuity and the nonviolent and non-confrontational nature of events. In my view, it is a misnomer as it deliberately overlooks the essentially politics- and power-driven substance of the process and, by design, fails to make any kind of moral distinction between the "before" and "after" spirit and normative content of laws and institutions.

"Constitutional revolution" was the label chosen by András Bozóki and his fellow editors and contributors to an 8-volume documentary collection and analytical commentary to characterize the outcome of the National Roundtable talks of the summer of 1989 which paved the way to free elections and the change of the political regime in March-April 1990. ${ }^{3}$ The formulation is attractive, yet it is still an oxymoron which fails to reconcile, in terms legitimacy and cognitive consonance, the yawning gap between the means, that is, an improvised legal artifact in the form of a modified constitution, and the ends, that is, revolution and the customary epistemological connotations of this term.

"Negotiated revolution," is my formulation, that depicts the events as a series of elite pacts which culminated in public endorsement of the outcome by free elections in March-April 1990. Such pacts, by the nature of the enterprise, tend to incorporate the negotiators short-term political and economic interests and hide their personal beliefs, ethical choices, and moral preferences. ${ }^{4}$ The point is that real revolutions are meant to be fought and won on the barricades rather than behind closed doors at the negotiating table. Moreover, real revolutions are ex- 
pected to yield moral and cognitive sea change, thus provide for a shared cathartic experience and, with it, the opening of a new page in the community's history. Therefore, the modifier "negotiated" is crucial to an understanding of what did and did not happen in 1989-1990. It is also the master key to comprehending how the people feel about political institutions, political processes and political actors today.

The main issue is the legacy of these events in terms of institutional outcomes, operating principles and political precedents and the way in which over the years these have been accepted, ignored or rejected by the Hungarian public.

Ten years after the fact, we are confronted with a paradox. On the one hand, Hungary strikes most foreign observers as a consolidated and outwardly stable parliamentary democracy; an arguably regional model of successful economic transformation; and, as the tourist posters claim, "the new spirit of old Europe."

On the other hand, the citizens of this new democracy, when asked about the great men of the past millenium, picked János Kádár as third behind St. Stephen and István Széchenyi, thus the top statesman of 20th century Hungary. Something is amiss here.

To make my case, I would like to submit three propositions.

(a) In the tenth year of an "existing democracy" a decisive majority of the Hungarian people have yet to come to terms with their nation's recent history and have yet to find their personal space in a democratic polity and market economy.

(b) Civil society, the traditional shelter for the norturing of the citizens' community spirit is still more of the old and the new local elites' normless political playground than a safe haven for the affirmation of personal values and civic virtues.

(c) Therefore, as demonstrated by countless surveys on citizen attitudes toward politics and political institutions, the non-elites still perceive their personal efficacy in public affairs in terms of voicelessness and powerlessness and are reluctant to attribute moral authority to political institutions.

Social psychologists speak of "deferred catharsis," "self-imposed amnesia" and a chronic sense of malaise. In my view, these labels, however accurate, are simplistic pathologies of complex cognitive processes that have been spawned by Hungary's rapid transformation from one type of political regime to another.

\section{Institutions and Moral Values}

The subject of this brief paper is institution-building and moral values and the way in which these are promoted or thwarted by Hungary's political class and the general public. 
By moral values I understand complex sets of privately held beliefs that have been shaped by personal and family histories, religious and secular norms, political exigencies, social and economic conditions and other extraneous circumstances. Hungary's troubled history that included a half dozen drastic political changes in the 20th century, tended to aggregate individual life experiences into generational clusters. The latter tend to penetrate and reshape personal judgments about right and wrong, fair and unfair, just and unjust, moral and immoral and, in the realm of public affairs, legitimate or illegitimate.

What are institutions? They are man-made legal artifacts whose purposes are specified in constitutions, laws and statutes which define the framework within which interactions between the citizens and the state take place. Traditionally, political institutions set norms, structure behavior, and regulate outcomes of interactions not only between the citizens and the government, but among key institutional actors, such as Parliament, the head of state, the courts, political parties, and local governments. The main point is that political institutions are elite-made instruments that embody the "architects" and, in the context of Hungary's negotiated revolution, the "founding fathers" material interests, personal values, and their vision of the public good.

Postcommunist Hungary's political institutions were crafted by two elites, each with clashing, as well as compatible values and interests. Both elites were products of the country's survivalist political culture which put premium on pragmatic compromise on the institutional-legal essentials and on the rolling over of intractable moral-ideological issues to be resolved by future generations. Accordingly, the National Roundtable negotiators of 1989 chose to set aside their ideological differences and, on the basis of shared short-term political interests, they sought the semblance of consensus, rather than agreements "carved in marble," for the sake of peaceful transition between two very different political systems.

Peaceful transition saves lives and property. Therefore, as a political strategy of choice, it must be seen as a morally and ethically superior alternative to violence or a civil war. On the other hand, institutions built on elite political compromises tend to be deficient with respect to legitimacy, that is, the public's moral and value identification with the process and its outcomes. Elite-orchestrated mass public participation in 1989, such as that on June 16 (for the ceremonial reburial of Imre Nagy and fellow victims of communist repression) and the "four question" referendum of September-November of that year (to deny the presidency to reform communist Imre Pozsgay) were preemptive moves to keep the masses off the streets to prevent the reenactement of the "people's (real) revolution" of 1956. 


\section{The House of Democracy and its Moral Guardians}

The institutional products of elite negotiations were components of an architectural blueprint for the nation's democratic political home. The building had a foundation of sorts in the form of a vague consensus on the ground rules of the democratic political game. The house was propped up by five institutional pillars: Parliament, the president of the Republic, the cabinet government, the party and the electoral system, and the Constitutional Court. The revised constitution served as the roof of the house, as well as a legal-ideological shelter for the protection of its inhabitants. ${ }^{5}$

Whereas four of the pillars were designed to serve as pragmatic instruments of policymaking and policy implementation, the Constitutional Court was the designated guardian of a law-governed state, that is, of public and private norms of lawful behavior.

This is how László Sólyom, the first President of the Court described the activist majority's constitutional philosophy:

The Constitutional Court's main objective was to develop the Constitution into a coherent system. It is questionable whether it is a moral principle. The Constitutional Court never stated that the basic law presupposes some kind of moral structure. Quite deliberately we did not wish to follow the German model which, particularly until the mid-1960s, generally spoke of a moral structure and other natural rights-derived antecedents. We also stressed that the Constitution, particularly since its modification in 1990 which eliminated all ideological language, is a neutral legal text. At the same time, it is quite clear that human rights are legal formulations for moral categories. The Constitutional Court perceived and extracted moral content, or with Dworkin's phrase, "moral reading," of each basic right according to the peculiarities of each of these rights. In doing so, it became unnecessary to cite generalities, such as the "value structure of the Constitution," thus moral principles became instrumentalized. We translated each moral right into the language of constitutional law, so that the Court could reasonably claim to have rendered judgment not on moral, but legal principles. ${ }^{6}$

\section{Political Rights as Welfare Entitlements}

The Hungarian constitution lists and protects two kinds of "human rights." The first is a cluster of the so-called "second generation" of negative rights, such as

freedom of speech, of assembly, of religion and so on. The second is a cluster of 
the so-called "third generation" of positive rights, such as the right to work, to social security, health, education, welfare, and a clean environment.

Now it is our turn to translate Sólyom's legal pieties into the language of politics.

Whereas the state's delivery on the citizens' negative rights is a relatively costfree proposition, in a market economy the satisfaction of public expectations associated with the citizens' social-welfare entitlements is a vastly different matter. These rights, and some new ones, were lifted, under the smoke screen of "legal continuity," intact from the old, communist-era constitution and became the public's, de facto socialist-era, moral yardstick by which to judge the performance of democratic institutions.

In my reading, the Court's "instrumentalization" of human rights was a key element of the "Founding Fathers"" reform socialist and left-liberal jurists' commitment to legal continuity. This, in turn, led to the relegitimation of the old regime's politically relatively uncompromised institutions, such as the state's technocracy and the judiciary. With respect to "positive rights," the same notion entailed the reaffirmation of the market-preemptive policies of state redistribution and, with it, the resuscitation of the much cherished, but economically unsustainable, socialist welfare package.

A brief detour. For understandable reasons, Kádár had been a vehement opponent of moral introspection. He used to say "we don't need soul-searching” (or in Hungarian, "nem kell nekünk lelkizés.") Instead, he defined the public good in consumerist terms with respect to access to food, shelter, welfare entitlements and restricted personal autonomy.

Much of this gave birth to the amoral rent-seeking world of the Homo Kádáricus. Under the old regime values of self-realization, civic probity, interpersonal trust and social solidarity were replaced by a Hobbesian world of unregulated pursuit of private interests (or érdekérvényesités in Hungarian) at the expense of the public good. In this world, ethical standards, altruism, and personal decency, let alone public profession of religious faith, became counterproductive to survival and success.

From the early 1970s on, Kádár's rule became a kind of 'soft dictatorship' and a normless 'live-and-let-live' pragmatic survival pact between the regime and the people, particularly the intellectuals. All but a handful of these one-time champions of liberty and national identity became coopted (and economically well-compensated) tools in the service of a coerced 'all-people's consensus' behind the regime's political objectives. In the age of 'soft dictatorship' Julien Benda's notion of the betrayal of the intellectuals was realized in Hungary in a massive and statistically demonstrable fashion. Alone in the Soviet bloc, Hungary had the dubious distinction of 40 percent of its ruling communist party's membership com- 
prised of intellectuals and holders of university degrees. The courageous few democratic, populist and reform socialist - dissident intellectuals tried to take the moral high road by staking a claim for the leadership of an alternative "second" society - albeit for and by the intellectuals, rather than for and by the people. Their definiton of the public good was, and could not be anything else, but a tribal affair rather than an agenda of moral emancipation of the unenlightened masses.

\section{Toward an Uncivil Society?}

Within the context of Hungary's negotiated revolution the accumulated moral deficit of the past could have been overcome by the public's extensive participation in various phases of systemic change. Instead, the elite negotiators kept the masses demobilized and dispensed what might be called 'catharsis by the spoonful.'

The pact-makers sought to legitimate their stance by targeting vaguely defined scapegoats, such as the "old regime," "lawless behavior by certain groups," and, of course, "Soviet rule," as the main culprits responsible for forty-five years of state-sponsored terrorism against the Hungarian people. Kádár somehow escaped criticism and during the 1990s became a nostalgic symbol of the normalcy of the "golden 1970s": that of limited political freedoms, attenuated morality, and severely eroded standards of civic probity. The elites' shared objective was to deflate the public's potentially revolutionary expectations. At the end, it was not a public referendum, but the outgoing Parliament's approval which gave birth to the constitution and the renaming of the state from a People's Republic to a (parliamentary) Republic. The bottom line: democracy "for the people" but definitely not "by the people."

According to Adam Przeworski, "Democratic institutions that fail to provide moral leadership cannot cope with conflicts arising from economic inequality and deprivation... Consent to democracy is contingent... on the congruence between the moral content of institutions and the basic values of society." 7

In the past ten years, hundreds of laws, several political parties, three governments, three Parliaments, the head of state, and two Constitutional Courts have been trying to fill the moral void with old and new values.

Of the three cabinet governments since 1990, József Antall's Christian democratic coalition had by far the most difficult task of simultaneously building democratic institutions and of trying to gain acceptance of traditional values (or indeed values of any kind) by the postcommunist public. It was a futile undertaking from the outset. Antall's proposed "value package" consisting of Populism, Christian

democracy and national liberalism struck the intended recipients, particularly the predominantly leftist intellectuals, as a hidden agenda for the restoration of the 
prewar Horthy regime's values and political style. Competing ideological paradigms, such as those offered by the left-liberal intellectuals, though helpful for discrediting the government's moral posturing, also failed to resonate with the disenchanted public.

The socialist-liberal government of 1994-1998 had no moral agenda of any kind. Instead, the regime stressed notions of expertise, modernization, and "Euroconformity." On the whole, it was a schizophrenic proposition: the old regime's third-echelon time-servers reinvented themselves as social democrats pursuing a value-free neoliberal agenda of marketization, while their liberal partners - most likely as a compensatory tactic to cover up for their mesaliance with their former political adversaries - extolled postmodern virtues by paying lip service to minority rights, gender equality and, above all, patronage/welfare for the intelligentsia. Terms, such as "nation," "patriotism," and citizen-Burgher (polgár) were expunged from the regime's official vocabulary.

It can be argued that the center-right Fidesz-Citizen's Party-led electoral coalition's victory in 1998 was due in equal measure to the voters' perception of widespread corruption by incumbent government party officials and to the spontaneous emergence of public yearning for the restoration of traditional civic values. The new regime promised to turn a new leaf by calling the electoral outcome a mandate not only for changing the government, but also hinted at measures with which to complete the unfinished process of political transformation from a postcommunist to a democratic regime.

As it may be inferred from the Orbán government's record after two years in office, there is still a wide gap between rhetoric and accomplishment. Manipulation of symbols, such as the transfer of St. Stephen's crown to the Parliament building and lip service to national identity and moral rectitude represent the plus side of the balance sheet. Widespread corruption - offical and private - brazen nepotism and continuing verbal warfare over ideological trivia are some of the key items on the debit side. Some of these liabilities may be dismissed as growing pains of a new democracy. However, the problem is that at the onset of the new millenium with the Fidesz regime the political class exhausted its diminishing supply of morally untainted politicians. The voters of 1998 expected youthful vigor and clean government, but got a brilliant, but willful and unpredictable prime minister and his disciplined team of earnest-looking young political piranhas bent on maximizing their grip on political, economic and cultural power.

In sum, throughout the 1990s the politicians' and their constitutional guardians' attempts at staking out the high ground of moral leadership has been considered and promptly rejected by a small army of media intellectuals and upheld by assorted party- or government-hired pens posing as authentic advocates of public interest. As it may be inferred from public opinion polls, people believe neither the politicians, nor the self-appointed intelligentsia spokesmen of moral virtue 
and political correctness. Their message simply does not resonate with the public's core beliefs.

The Hungarian public's core beliefs are similar to those of its Central European postcommunist neighbors. These consist of a strong sense of national identity; deep frustrations over deferred social and political justice; ambivalent-tohostile attitudes toward market economy and capitalism in general: fear and trepidation toward globalization and European integration; and, above all, distrust of authority of any kind, especially the state. A decade's worth of democratic institution building has yet to yield the acceptance and internalization of implicit beliefs in law and order and the primacy of the public good over greed, distrust and unbridled individualism. It is not a pretty picture.

What is missing from the cognitive equation is a new kind of political culture and a new consensus on the public good. These call for civil courage to come to terms with the past, the embracing of a new democratic identity, the acceptance of the new rules of the political game and of the giving the benefit of doubt to freely elected politicians, lawful insitutions, and fellow citizens alike. None of this is going to happen anytime soon. The house of democracy is still under construction in Hungary today.

\section{Notes}

1. Timothy Garton Ash, "Refolution, the Springtime of Two Nations," New York Review of Books, July 5, 1989.

2. cf. Béla Király and András Bozóki, eds, The Lawful Revolution in Hungary, 1989-1994 (Boulder: Social Science Monographs, 1994).

3. András Bozóki et al., eds, Alkotmányos forradalom. Tanulmányok [Constitutional revolution. Studies] (Budapest: Új Mandátum, 2000) vol. 7 of András Bozóki et al., eds, A rendszerváltás forgatókönyve. A kerekasztal tárgyalások 1989-ben. [Change of the regime in Hungary - Scenarios. The National Roundtable Negotiations of 1989] ( Budapest: Új Mandátum, 2000) 8 vols.

4. Rudolf L. Tőkés, Hungary's Negotiated Revolution: Economic Reforms, Social Change and Political Succession, 1957-1990 (Cambridge: Cambridge University Press, 1996, 1998).

5. On this see, Rudolf L. Tőkés, "Intézményalkotás Magyarországon: elemzési szempontok, alkotmányos modellek, 1989" [Institution-building in Hungary: analytical issues and constitutional models] in: Bozóki et al., eds, Alkotmányos forradalom, 147-179.

6. “A 'nehéz eseteknél' a bíró erkölcsi felfogása jut szerephez. Sólyom Lászlóval az Alkotmánybíróság elnökével Gábor Attila beszélget” [In difficult cases the judge's moral conceptions play a role. Interview with László Sólyom, president of the Constitutional Court], Fundamentum No. 1, 1997

7. Adam Przeworski et al., Sustainable Democracy (New York: Cambridge University Press, 1995), 42. 